\title{
Correction: The relatively young and rural population may limit the spread and severity of COVID-19 in Africa: a modelling study
}

Diop BZ, Ngom M, Pougué Biyong C, et al. The relatively young and rural population may limit the spread and severity of COVID-19 in Africa: a modelling study. BMJ Global Health 2020;5: e002699.

This article has been corrected since it published online to include the below funding information:

Binta Zahra Diop's PhD is funded by the Center for the Study of African Economies and the Global Challenges Research Fund. Marieme Ngom's work was supported by the U.S. Department of Energy, Office of Science, under Contract DE-AC02-06CH11357. Clémence Pougué Biyong's PhD is funded by the French Ministry of Higher Education and Ecole Normale Supérieure of Rennes. John N. Pougué Biyong's PhD is funded by the UK Engineering and Physical Sciences Research Council (EPSRC).

\begin{abstract}
Open access This is an open access article distributed in accordance with the Creative Commons Attribution Non Commercial (CC BY-NC 4.0) license, which permits others to distribute, remix, adapt, build upon this work non-commercially, and license their derivative works on different terms, provided the original work is properly cited, appropriate credit is given, any changes made indicated, and the use is non-commercial. See: http://creativecommons.org/licenses/by-nc/4.0/.
\end{abstract}

(C) Author(s) (or their employer(s)) 2020. Re-use permitted under CC BY-NC. No commercial re-use. See rights and permissions. Published by BMJ.

BMJ Global Health 2020;5:e002699corr1. doi:10.1136/bmjgh-2020-002699corr1 